\title{
Responses Growth and Yield of Three Shallot Cultivars in Sandy Coastal Land with PGPR (Plant Growth Promoting Rhizobacteria)
}

\author{
Sumiyati Tuhuteru", Endang Sulistyaningsih", Arif Wibowo* \\ ${ }^{\#}$ Department of Agronomy, Faculty of Agriculture, Gadjah Mada University, Yogyakarta, 55281, Indonesia \\ *Department of Plant Diseases, Faculty of Agriculture, Gadjah Mada University, Yogyakarta, 55281, Indonesia \\ E-mail: tuhuteru.umy@gmail.com
}

\begin{abstract}
Plant Growth Promoting Rhizobacteria (PGPR) is a group of bacteria rhizosphere used to a biological fertilizer on agricultural activities. The purpose of this research got the kind of PGPR which was effective against the growth of three cultivars at sandy coastal land. The research was conducted from August - November 2015 in coastal sandy land Samas-Bantul. This research used a randomized block design (RCBD) with two factor such us cultivar of shallot and suspension PGPR. The first factors were the Crok cultivar, Tiron, and Tuk-tuk and the second factors were Control (without PGPR), PGPR isolates BP25.2 (Bacillus methylotrophic), BP25.6 (Bacillus amyloliquofaciens), BP25.7 (Bacillus subtilis), BrSM 4 (Burkholderia cepacian), and BrSG 5 (Burkholderia seminalis). Data were analyzed by using ANOVA $\alpha 5 \%$. If there were a significant difference between treatments, so it was analyzed by DMRT $\alpha$ 5\%. Results showed significant through interactions every variable generated, such as isolates BP25.2 that can enhance seed vigor index Tiron cultivars, isolates BrSG 5 and BP25.7 capable of inducing number of leaves in the vegetative phase and is capable of stimulating content proline in the face of stress shallot plant at sandy coastal, isolates BrSM 4 is able to increase the number of total chlorophyll Tuk-tuk cultivars and isolates BrSG 5 is able to increase the dry weight of bulbs production Tuk-tuk cultivars.
\end{abstract}

Keywords - shallots; PGPR; sandy coastal land

\section{INTRODUCTION}

Shallots are vegetable crops, which have long been intensively cultivated by farmers. The main producing provinces are marked with shallot harvest area exceeding a thousand hectares per year are North Sumatra, West Sumatra, West Java, Central Java, Yogyakarta, East Java, West Nusa Tenggara, Central Sulawesi and South Sulawesi. These eight provinces accounted for $96.8 \%$ of the total shallot production in Indonesia in 2013. Meanwhile, the five provinces in Java Island which consist of West Java, Central Java, Yogyakarta, East Java, and Banten are contributed $78.1 \%$ of the total shallot yield nationwide. Average consumption of shallots per capita for 2011-2012 ranged from $2.36 \mathrm{~kg} /$ year and 2.74 $\mathrm{kg} /$ year [2].

Shallots are spread in almost all parts of Indonesia. In 2015, exports of shallot soared $219 \%$. Correspondingly, shallot imports fell $82 \%$ in the same period. Based on data from the Ministry of Agriculture [2], national shallot yield in 2015 reaches 1.265 million tons, while the demand is only 947.385 ton. Thus, the national shallot production surplus is 318.325 ton, [2]. Therefore, in order to maintain the results achieved, the use of marginal lands, as the coastal sandy need to improve and then alternative substitution of manure [13], as PGPR. Along with the use of biological fertilizers, combining with fertilizer use organic materials known very well be used to improve the physical and biological properties of soil, improve the effectiveness of soil microorganisms and more friendly to the environment [17].

Plant Growth Promoting Rhizobacteria (PGPR) is one of a group bacteria rhizosphere biological fertilizer used in agriculture. PGPR is one of the microbes using alternative chemical fertilizer [8]. In addition, PGPR application usage is expected to increase the growth and productivity of shallot crop cultivated in the sandy coastal land, so constraints the land in farming can be minimized [11]. PGPR is known for its ability to provide and mobilize or facilitate the absorption of various nutrients in the soil as well as synthesizing and changing the concentration of various phytohormone hyper growth. In addition, its functions related to the ability to 
suppress the activity of pathogens by producing various compounds or metabolites such as antibiotics and siderophore [6], [7], and [3]. Plant growth which involves rhizobacteria through several activities directed applicative have been shown an increase in plant growth and development through the use of biological agents or microorganisms [15].

In reference [5], indicating that these isolates the PGPR bacterial group having the ability as bioprotectant, which are useful for controlling diseases of Moler. These isolates are BP25.2 (Bacillus methylotrophic), BP25.6 (Bacillus amyloliquofaciens), BP25.7 (Bacillus subtilis), $\mathrm{BrSM} 4$ (Burkholderia cepacian), and BrSG 5 (Burkholderia seminalis). This research aimed to determine the effect of PGPR on growth and development of three cultivars at sandy coastal land, hoping to obtain information types and kinds of PGPR with cultivars suitable for use in the cultivation of sandy coastal land.

\section{MATERIAL AND METHODS}

The research was conducted on sandy coastal land Samas Bantul, Yogyakarta, from August 2015 - November 2015. Seeds of shallot cultivars Crok, Tiron, and Tuk-tuk. Meanwhile, the materials used PGPR isolates BP25.2 (Bacillus methylotrophic), BP25.6 (Bacillus amyloliquofaciens), BP25.7 (Bacillus subtilis), BrSM 4 (Burkholderia cepacian), and BrSG 5 (Burkholderia seminalis).

The research was set in a randomized block design (RCBD) 2 factors with 3 blocks as replicates. The first factor is cultivars, namely Crok (K1), Tiron (K2) and Tuk-tuk (K3). The second factor that PGPR suspension; control treatment (B0), treatment of PGPR isolates of Bacillus methylotrophic (B1), the treatment of PGPR isolates of Bacillus amyloliquofaciens (B2), treatment of PGPR isolates of Bacillus subtilis (B3), the treatment of PGPR isolates of Burkholderia cepacian (B4), and the treatment of PGPR isolates of Burkholderia seminalis (B5).

The next stage was the making of PGPR suspension. Prepared petri dish and a single colony for each PGPR suspension. After 30 minutes the media were sterilized cooled and then poured into each Erlenmeyer. Afterward, shaken until it reached 106-108 OD (Optical Density) for 3x stages of dilution, for $3 \mathrm{~L}$ of an aqueous suspension was required. Furthermore, after the media were given each isolate PGPR, and then poured into a petri dish evenly with a thickness of \pm $1-2 \mathrm{~cm}$. Furthermore, seeds were soaked in $120 \mathrm{ml}$ of PGPR was added water up to $3 \mathrm{~L}$, for \pm 8 hours. Then dried in the shade before planting. The next stage was planting. Then, fertilization was done at the time the plant was \pm 5 days after planting. Fertilization used inorganic fertilizers such as ZA 200 $\mathrm{kg}$. Advanced fertilization performed at the time the plant was 15 days after planting using $90 \mathrm{~kg}$ of urea and TSP $170 \mathrm{~kg} / \mathrm{ha}$. Then, also carried out in the accordance care technical field. Caterpillar pest control such as shallots (Spodoptera exigua or $S$. litura) with active insecticide spraying emamektin benzoate $22 \mathrm{~g} / \mathrm{L}$, chlorfenapyr $360 \mathrm{~g} / \mathrm{L}$, and diafentiuron $500 \mathrm{~g} / \mathrm{L}$. Spraying was done by spraying a duration of 2 times a week.
The data observed consist of index vigor, plant height $(\mathrm{cm})$ and the number of leaves on the observation 1, 3 and 5 weeks after planting, leaf area index (LAI), net assimilation rate (NAR), relative growth rate (RGR), analyzes of proline at 5 Weeks After Planting and bulb dry weights at 9 Weeks After Planting.

The data result of observations analyzed using ANOVA (Ftest) at 5\% level. If the test results indicated a real influence or very real, the test continued with Duncan's Multiple Range Test (DMRT) at test level 5\%.

\section{RESULTS AND DISCUSSION}

\section{A. Index Vigor of Shallot Seeds}

That results shows the interaction between PGPR extra with cultivars being tested. Isolates BP25.2 with Tiron cultivars shows the highest rates of $100.00 \%$ (Table 1). The interaction between PGPR with cultivars tested shows that PGPR role in the biochemical processes that affect plant vigor index indicated. Moreover, this demonstrates the ability of cultivars in response to PGPR extra allegedly is caused by the ability of isolates rhizobacteria in producing growth hormones. The BP25.2 isolate of bacteria genus Bacillus is widely reported as a producer phytohormone in large numbers, especially IAA to stimulate growth [16].

IAA is a group of growth hormone auxin that is useful to stimulate plant growth. In addition, according to [4], that Pseudomonas is producing the hormone in the form of Indole Acetic Acid (auxin) that stimulate the growth of plant shoots. The auxin to stimulate growth and development of plant organs by elongation and the addition of the plant cell. It can also be associated with PGPR ability to provide N, P, and Mn is known $\mathrm{N}$ works in the formation or growth of vegetative parts of the plant and $\mathrm{N}$ as well as hyperproliferation of microorganisms in the soil. Meanwhile, $\mathrm{P}$ is known to stimulate root formation of bulbs or young plants, as well as Mn which is an activator of enzymes in the plant body.

\section{B. Plant Height (cm) and Number of Leaves}

PGPR gives treatment no significant effect on plant height shallot parameter at 1, 3 and 5 Weeks after Planting, but each looks isolates shows a different effect on each cultivar tested. It is suspected that the plant is active in the process of metabolism and then into mature plants, where the high growth of plant cultivars Crok at 1 Weeks After Planting, BP25.7 PGPR isolates shows the highest plant height, while the 3 Week After Planting BP25.6 PGPR isolates shows the highest plant height (Fig. 1). Furthermore, for observation 5 Week after Planting BP25.2 PGPR isolates shows the highest plant height. Cultivars Tiron shows BP25.2 PGPR isolates the highest plant height at 1 Week after Planting, whereas on 3 Week After Planting BP25.6 PGPR isolates shows the highest plant height. Compared to the 5 Week after Planting, without the addition of PGPR treatment (control) shows the highest plant height (Fig. 2). Then, for the cultivar Tuk-tuk at 1 Week After Planting seen PGPR isolates BrSG 5 shows the highest 
plant height, while the 3 and 5 Week After Planting BP25.7 PGPR isolates shows the highest plant height (Fig. 3).

TABLE I

SEEd Vigor InDEX ON OBSERVATIONS 7 DAY AFTER Planting

\begin{tabular}{|c|c|c|c|c|c|c|c|c|}
\hline \multirow{2}{*}{ Parameter } & \multirow{2}{*}{ Cultivars } & \multicolumn{5}{|c|}{ PGPR Treatment } & \multirow[b]{2}{*}{ BrSG 5} & \multirow{2}{*}{ Average } \\
\hline & & Control & BP25.2 & BP25.6 & BP25.7 & BrSM 4 & & \\
\hline \multirow{4}{*}{$\begin{array}{l}\text { Seed Vigor } \\
\text { Index }\end{array}$} & Crok & $55.56 \mathrm{bc}$ & $55.56 \mathrm{bc}$ & $77.78 \mathrm{ab}$ & $77.78 \mathrm{ab}$ & $33.33 \mathrm{c}$ & $77.78 \mathrm{ab}$ & 62.96 \\
\hline & Tiron & $66.67 \mathrm{abc}$ & $100.00 \mathrm{a}$ & $66.67 \mathrm{abc}$ & $88.89 \mathrm{ab}$ & $77.78 \mathrm{ab}$ & $55.56 \mathrm{bc}$ & 75.92 \\
\hline & Tuk-tuk & $33.33 \mathrm{c}$ & $88.89 \mathrm{ab}$ & $66.67 \mathrm{abc}$ & $88.89 \mathrm{ab}$ & $77.78 \mathrm{ab}$ & $55.55 \mathrm{bc}$ & 68.52 \\
\hline & Average & 51.85 & 81.48 & 70.37 & 85.19 & 62.96 & 62.96 & $(+)$ \\
\hline
\end{tabular}

Description: The numbers in the columns and/or rows followed by the same letter are not significantly different according to Duncan Multiple Range Test with $\alpha=$ $5 \% ;(+)$ : No interaction between factors being tested.

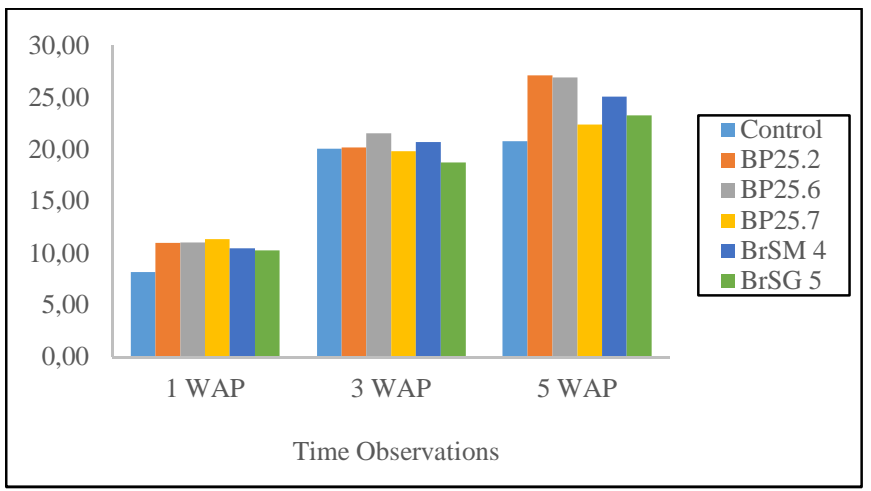

Fig. 1 Plant height of shallots cultivar crok in observation 1,3 and 5 weeks after planting

Similarly, plant height, the number of parameters of each leaf isolates shows a different the effect on each cultivar tested. It is seen that the highest number of leaf cultivars Crok at 1 and 3 Week after Planting shown by BP25.7 PGPR isolates, while the highest a number of leaves at 5 Week After Planting is shown by PGPR isolates BP25.2 (Fig. 4). Furthermore, for the cultivar Tiron, the highest number of leaves at 1 Week After Planting is shown by PGPR isolates BP25.2, and at 3 and 5 Week After Planting the highest a number of leaves are indicated by PGPR isolate BrSM 4 (Fig. 5). Then for cultivars, Tuk-tuk highest number of leaves at 1 and 3 Week after Planting is shown by PGPR isolates BrSG 5, while the fifth highest number of leaves Week After Planting is shown by PGPR isolates BP25.7 (Fig. 6).

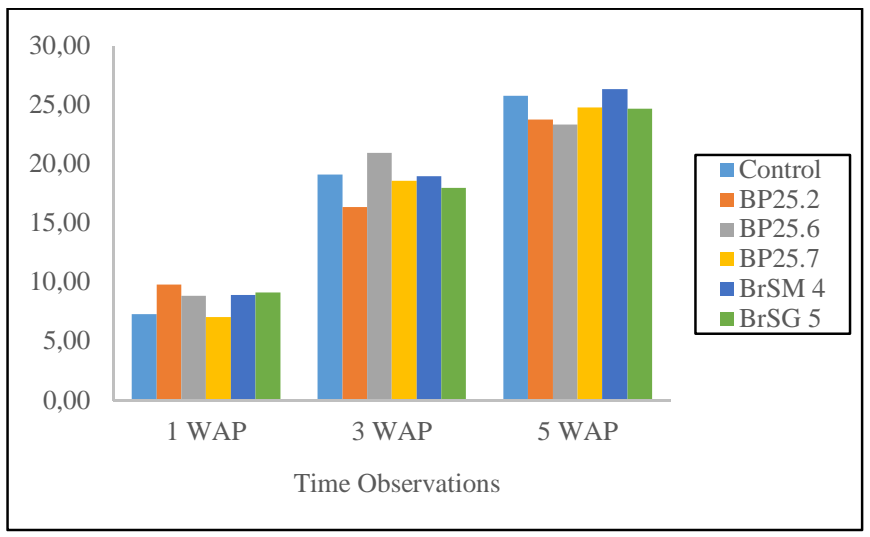

Fig. 2 Plant height of shallots cultivar tiron in observation 1, 3 and 5 weeks after planting

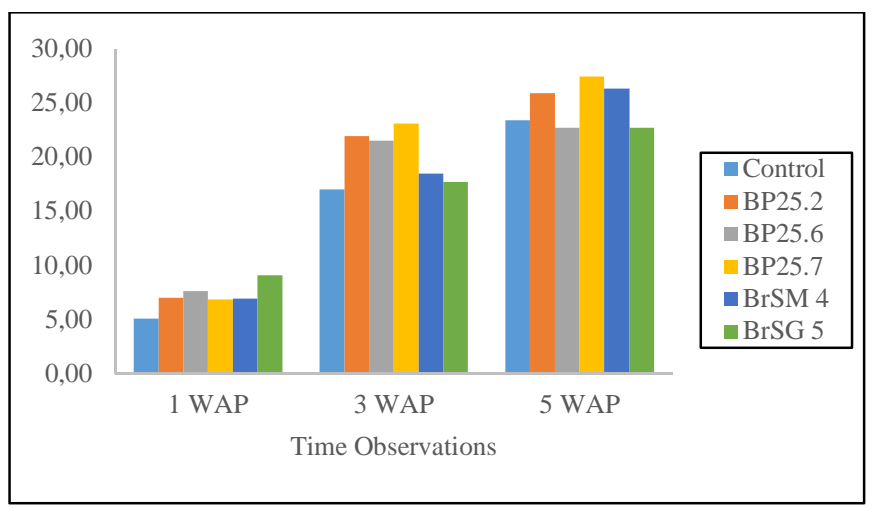

Fig. 3 Plant height of shallots cultivar tuk-tuk in observation 1, 3 and 5 weeks after planting 


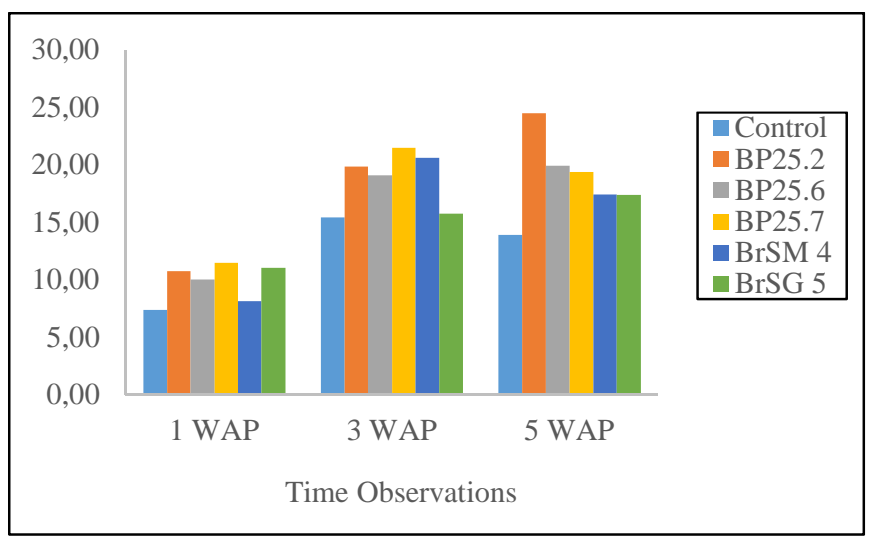

Fig. 4 Number of leaf cultivar crok in observation 1, 3 and 5 weeks after planting

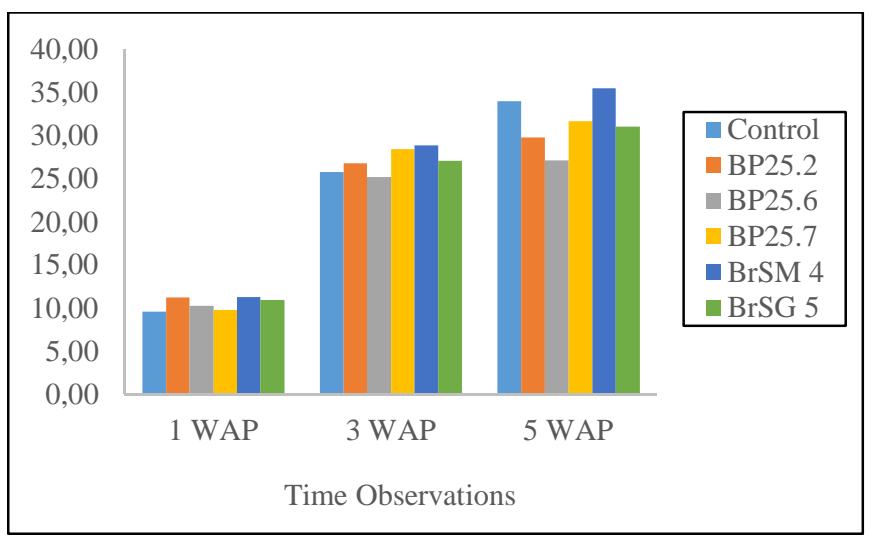

Fig. 5 Number of leaf cultivar tiron in observation 1, 3 and 5 weeks after planting

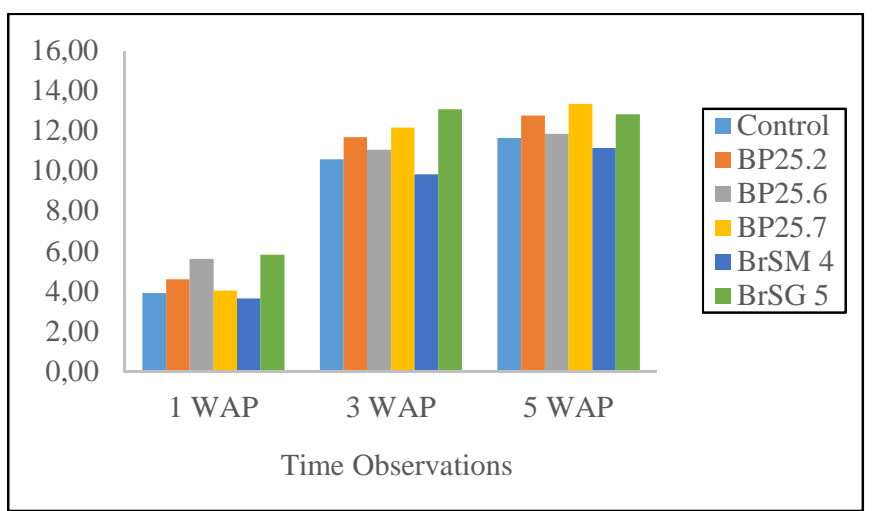

Fig. 6 Number of leaf cultivar tuk-tuk in observation 1, 3 and 5 weeks after planting

The number of leaves response of each cultivar was observed showing Tiron cultivars, showed the best response with the highest number of leaves followed by Crok then Tuktuk. This is presumably related to the ability of Tiron which is able to adapt in sandy areas as well as land, besides cultivars Tiron has the ability to produce many tillers so that the number of leaves produced is far more than the cultivars Crok and Tuk-tuk [1].
The results show that plant height and number of leaves are more influenced by the bacterium Bacillus which is one of the PGPR group that has a role in improving plant growth and development. High growth and development of plants occurs due to cell division, cell elongation, cell formation and the formation of new tissue requires carbohydrates which the synthesis of carbohydrates is heavily influenced by the ability of plants to perform photosynthesis, so that the rate of growth and cells elongation and the formation of the tiller running fast, then the growth of the stem, leaf and the roots will run fast. It happens allegedly affected by the presence IAA hormones in plant body and in the strains used, which affects plant growth and development phase [10].

\section{Leaf Area Index, Net Assimilation Rate, Relative Growth Rate, Proline Content}

PGPR observation ability test against leaf area index, net assimilation rate, relative growth rate, and the proline content of shallot plants in 5 Week after Planting, observation (Table 2).

TABLE II

LEAF AREA Index, Net Assimilation Rate, RATE of GRowth RElative, Proline of Shallot CUltivars CroK, TIRON AND TUK_TuK IN OBSERVATIONS 5 WEEK AFTER PLANTING

\begin{tabular}{|c|c|c|c|c|}
\hline \multirow{2}{*}{ Treatments } & \multicolumn{4}{|c|}{ Parameters } \\
\hline & LAI & NAR & RGR & Proline \\
\hline \multicolumn{5}{|l|}{ Cultivars } \\
\hline Crok & $0.34 \mathrm{~b}$ & $0.15 \mathrm{a}$ & $0.74 \mathrm{~b}$ & $32.65 \mathrm{a}$ \\
\hline Tiron & $0.47 \mathrm{a}$ & $0.15 \mathrm{a}$ & $0.93 \mathrm{a}$ & $2247 \mathrm{a}$ \\
\hline Tuk-tuk & $0.29 \mathrm{~b}$ & $0.17 \mathrm{a}$ & $0.87 \mathrm{ab}$ & $22.10 \mathrm{a}$ \\
\hline \multicolumn{5}{|l|}{ PGPR } \\
\hline Control & $0.32 \mathrm{a}$ & $0.20 \mathrm{a}$ & $0.90 \mathrm{a}$ & $23.96 \mathrm{bc}$ \\
\hline BP25.2 & $0.38 \mathrm{a}$ & $0.15 \mathrm{ab}$ & $0.83 \mathrm{a}$ & $33.74 \mathrm{ab}$ \\
\hline BP25.6 & $0.35 \mathrm{a}$ & $0.12 \mathrm{~b}$ & $0.78 \mathrm{a}$ & $11.85 \mathrm{c}$ \\
\hline BP25.7 & $0.41 \mathrm{a}$ & $0.15 \mathrm{ab}$ & $0.91 \mathrm{a}$ & $47.67 \mathrm{a}$ \\
\hline BrSM 4 & $0.42 \mathrm{a}$ & $0.16 a b$ & $0.82 \mathrm{a}$ & $2073 \mathrm{bc}$ \\
\hline BrSG 5 & $0.33 \mathrm{a}$ & $0.17 \mathrm{ab}$ & $0.82 \mathrm{a}$ & $16.48 \mathrm{c}$ \\
\hline \multirow[t]{2}{*}{ CV } & 8.04 & 4.60 & 25.80 & 27.12 \\
\hline & $(-)$ & $(-)$ & $(-)$ & $(-)$ \\
\hline
\end{tabular}

Description: The numbers in the column followed by the same letter are not significantly different according to Duncan Multiple Range Test with $\alpha=5 \%$; $(-)$ : There is no interaction between factors being tested; Data transformed with $\log \sqrt{(x+0,5)}$

This result shows significantly different influence on the parameters indicated by leaf area index of cultivars and relative growth rate. Tiron cultivars response give a good influence on the provision of PGPR shown on the parameters of leaf area index and relative growth rate. This is related to the ability of plants to absorb solar radiation in the form assimilates to the process of photosynthesis, which assimilates 
that is absorbed by the leaves used in the formation of bulbs, and Tiron cultivars is a cultivar known to have a number of leaves most, so the alleged effect in absorbing solar light and also has an effect on relative growth rate compared to other cultivars. Meanwhile, Tuk-tuk cultivars able to express well in the sandy coastal land as Tiron and Crok, even Tuk-tuk is same as Tiron, because it has been known that the ability Tiron known as a bulb that can grow on sandy coastal land. Meanwhile, PGPR treatment of the results of the analysis showed no real influence or can be said to be the ability of PGPR will look at variables that indicate the presence of a physiological response to the plant. Thus, has not shown a significant influence.

PGPR treatment shows a real influence on the parameters net assimilation rate and proline content of plants. However, net assimilation rate is indicated by the control (no treatment) with the highest mean value. It is stated that, the plant without giving isolates PGPR on 5 Week After Planting observations capable of absorbing light radiation and high assimilation of $\mathrm{CO}_{2}$ when the growth phase, otherwise PGPR as phytohormone assumed to be able to increase the vegetative growth of the plants, so that both show the same response in enhancing the growth of vegetative plants. In addition, the provision of PGPR seen showed a significant the effect on the cultivars under stress. Seen that, PGPR isolates BP25.7 significant influence amounted to $47.67 \mathrm{~mol} / \mathrm{g}$, which allegedly isolates respond more quickly from environmental stress. This demonstrates the ability of the plant tolerance in the face of environmental stress thus increasing plant proline content.

Proline is a free amino acid is formed and accumulates on the leaves in an amount more when plants experience drought stress. Proline also plays an important role in the avoidance of dehydration by increasing cell solute content and also maintain water levels remain high. At the same time, the accumulation of proline a role against dehydration tolerance by protecting proteins and membrane structures [14].

\section{Chlorophyll Plant}

The content of total chlorophyll in the plant body associated with the amount is absorbed by plants assimilate in generating production. The results of the research show the interaction between PGPR treatment with shallot cultivars with the highest rates generated by cultivar Tuk-tuk combination with isolated PGPR BrSM $4(0.31 \mathrm{~nm})$. It is suspected Tuk-tuk is a type of plant that more stores when the light absorption of nutrients, $\mathrm{CO}_{2}$, water and other nutrients and use them in the generative phase, compared with the vegetative phase. It is seen from the amount of leaf area index values are low, of the size of the plant height and a number of leaves formed too low. Thus, it is thought to affect the rate of plants photosynthesis so the effect on total chlorophyll content of plants (Table 3)

Chlorophyll content indicates the level of formation of assimilates in increasing plant yields. In addition, related to the presence of bacteria interaction with plants, allegedly closely associated with one of the functions PGPR as phytohormones in plants that besides being able to provide hormone growth for plants, bacteria PGPR also able to increase nutrient content, especially around each area rhizosphere, particularly in synthesizing N. In reference [9], which explains that the role of nitrogen for plants is to stimulate overall growth, specially branches, stems, and leaves. Nitrogen serves as a shaper of chlorophyll, protein, and fat. Nitrogen also as a constituent of enzymes found in the cell, thus affecting the formation of carbohydrates which is instrumental in the growth of plants.

The results of this study suggested that the amount of chlorophyll that is formed is determined by the presence of bacteria in interacting with each cultivar known that whether or not a plant growth depends on physiological processes that take place in the body of the plant, which is expressed from the interaction data from the analysis of plant tissue, such as the amount of chlorophyll.

TABLE III

TOTAl Chlorophyll Shallot CUltivars CROK, TIRON ANd TUK-TUK IN OBSERVATION 5 WeEK AFTER Planting

\begin{tabular}{|c|c|c|c|c|c|c|c|c|}
\hline \multirow{2}{*}{ Parameters } & \multirow{2}{*}{ Cultivar } & \multicolumn{6}{|c|}{ PGPR Treatment } & \multirow{2}{*}{ Average } \\
\hline & & Control & BP25.2 & BP25.6 & BP25.7 & BrSM 4 & BrSG 5 & \\
\hline \multirow{5}{*}{$\begin{array}{c}\text { Chlorophyll } \\
\text { Total }\end{array}$} & Crok & $0.17 \mathrm{abc}$ & $0.14 \mathrm{bc}$ & $0.10 \mathrm{c}$ & $0.16 \mathrm{abc}$ & $0.10 \mathrm{c}$ & $0.16 \mathrm{bc}$ & 0.138 \\
\hline & Tiron & $0.13 \mathrm{c}$ & $0.21 \mathrm{abc}$ & $0.11 \mathrm{c}$ & $0.12 \mathrm{c}$ & $0.11 \mathrm{c}$ & $0.10 \mathrm{c}$ & 0.13 \\
\hline & Tuk-tuk & $0.12 \mathrm{c}$ & $0.15 \mathrm{bc}$ & $0.27 \mathrm{ab}$ & $0.18 \mathrm{abc}$ & $0.31 \mathrm{a}$ & $0.09 \mathrm{c}$ & 0.19 \\
\hline & Average & 0.14 & 0.17 & 0.16 & 0.152 & 0.173 & 0.11 & $(+)$ \\
\hline & \multicolumn{8}{|c|}{ CV: 21.52} \\
\hline
\end{tabular}

Description: The numbers in the columns and rows followed by the same letter are not significantly different according to Duncan Multiple Range Test with $\alpha=5 \%$; (+): No interaction between factors being tested.

\section{E. Weight Bulb Production}

Results show that the interaction of cultivars with PGPR treatment on parameters yield of bulb dried (Table 4). From the whole of this combination, the best result is shown by cultivars Tiron combined with the treatment of PGPR isolates
BrSG 5. Tiron cultivars show the highest rates when combined with the treatment of PGPR isolates BrSG 5 (1.86 ton/ha) are significantly different with Crok combined with PGPR BP25.7 and tuk-tuk combined with PGPR isolates BrSG 5.

Increased dry weight can occur when photosynthesis is greater than respiration. This is evidenced by the number of 
total chlorophyll content in plants which is a basic ingredient in the process of photosynthesis, where Tuk-tuk cultivars showed high total chlorophyll content, though interactions are indicated by different types of bacteria. However, both bacteria derived from bacterium genus Burkholderia. The activity of bacteria in plant his role as the alleged phytohormone particularly IAA can be expected to increase the permeability of cell walls which will increase the absorption of nutrients forming chlorophyll indispensable to enhance photosynthesis and the effect on plant production.

TABLE IV

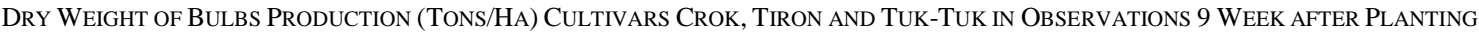

\begin{tabular}{|c|c|c|c|c|c|c|c|}
\hline \multirow{2}{*}{ Cultivar } & \multicolumn{6}{|c|}{ PGPR Treatment } & \multirow{2}{*}{ Average } \\
\hline & Control & BP25.2 & BP25.6 & BP25.7 & BrSM 4 & BrSG 5 & \\
\hline Crok & $0.88 \mathrm{bcd}$ & $0.75 \mathrm{bcd}$ & $1.00 \mathrm{bcd}$ & $0.11 \mathrm{f}$ & $0.67 \mathrm{de}$ & $0.51 \mathrm{def}$ & 0.65 \\
\hline Tiron & $1.56 \mathrm{ab}$ & $1.1 \mathrm{abcd}$ & 0.99 abcd & $1.55 \mathrm{ab}$ & $1.54 \mathrm{abc}$ & $1.86 \mathrm{a}$ & 1.44 \\
\hline Tuk-tuk & 0.62 cde & $0.78 \mathrm{bcd}$ & $0.38 \mathrm{def}$ & $0.18 \mathrm{ef}$ & $0.62 \mathrm{de}$ & $0.11 \mathrm{f}$ & 0.45 \\
\hline Average & 1.02 & 0.89 & 0.79 & 0.61 & 0.94 & 0.83 & $(+)$ \\
\hline
\end{tabular}

Description: The numbers in the columns and/or rows followed by the same letter are not significantly different according to Duncan Multiple Range Test with $\alpha=$ $5 \%$; (+): No interaction between factors being tested; Data transformed with $\log \sqrt{(\mathrm{x}+0.5)}$

Auxin works primarily to soften the cell walls resulting in increased water uptake by cells that cause the cell to swell. Additionally, allegedly as a result of the nutrient content of manure given and with the help of bacteria in the plant tissues, can be absorbed by the plant's metabolic processes such as the formation of carbohydrates which are mostly translocation to bulbs.

In this phase of potassium plays a role in the formation and enlargement of the bulbs. Thus, a good interaction suspected because of the interaction of manure given as basal fertilizer with the treatment of PGPR that spurs the growth hormone that causes ovule grow even more, as expressed by [12] that PGPR important role in improving plant growth, yield and fertility of the land. In addition, related to the presence of hormone auxin in the plant body is able to increase the osmotic pressure so that the plant will increase the absorption of water by the cultivar [4].

\section{CONCLUSION}

The results showed that the isolates used include PGPR bacteria that can be used in the cultivation of shallot in the sandy coastal land with the combination treatment were obtained: Isolate BP25.2 is able to increase seed vigor index of Tiron cultivars; Isolate BP25.7 is capable of inducing the number of leaves on the plant vegetative phase. Additionally, isolates BP25.7 stimulates proline content in the face of stress shallot plant at sandy coastal land; Isolate BrSM 4 is able to increase the number of total chlorophyll Tuk-tuk cultivars; Isolate $\mathrm{BrSG} 5$ is able to stimulate the formation of leaves and increase the dry weight of bulbs production of Tuk-tuk cultivars.

\section{ACKNOWLEDGMENT}

I would like to thank the Indonesia Endowment Fund for Education (LPDP) for the financial support for this research.

\section{REFERENCES}

[1] Ambarwati and Yudhoyono, 2003. The diversity of the stability of the onion, UGM. Yogyakarta.

[2] Directorate General Ministry of Agriculture of the Republic of Indonesia. Shallot production in Indonesia. 2015. http://m.detik.com/finance/read/2015/06/11/133928/2939608/4/. (4/1/2016).

[3] Glick. B.R. 1995. The Enhancement of Plant Growth by Free-Living Bacteria. Can. J. Microbial. 4: 1009-117.

[4] Hasanuddin. 2003. Increasing Role of Microorganisms Natural Plant Disease Control Systems Integrated. Faculty of Agriculture USU. North Sumatra.

[5] Istiqomah D. 2015. Selection Rhizobacteria of Shallots for Control Moler Disease. Thesis. Department of Phytopathology. Faculty of Agriculture. Gadjah Mada University. Yogyakarta.

[6] Kloepper J. W., W. Mahaffee. J.A. Mcinroy and P.A. Backman. 1991. Comparative Analysis of Isolation Methods for Recovering Rootcolonizing Bacteria from Roots. p. 252-255. In C. Keel. B. Koller and G. Defago (Eds.). Plant Growth Promoting Rhizobacteria - Progress and Prospects. The second International Workshop on PGPR. Interlaken. Switzerland. October 14-19. 1990.

[7] Kloepper. J.W. 1993. Plant Growth Promoting Rhizobacteria as Biological Control Agents. p. 255 - 274. In F.B. Meeting. Jr. (Ed.) Soil Microbial Ecology. Applications in Agricultural and Environmental Management. Marcel Dekker. Inc. New YorkR. E. Sorace, V. S. Reinhardt, and S. A. Vaughn, "High-speed digital-to-RF converter," U.S. Patent 5668 842, Sept. 16, 1997.

[8] Nugroho A. W., Nurlaili R. F., Hendrawan Y., Argo D. B. 2015. Effect of Growth Promoting Bacteria on the Growth Rate and Lipid Content of Microalgae Chorella sp. in Sludge Liquor of Anaerobic Digester Dairy of Manure. Journal. Ijaseit: Vol.5 (2015) No. 5 ISSN: 2088-5334

[9] Prayitno A. 2015. Response Giving Dolomite Lime and Fertilizer Granule Modern Organic on Growth and Results of Shallot (Allium ascalonicum L.) On Sand Land. Essay. Faculty of Agriculture. The University of Muhammadiyah Palangkaraya.

[10] Putri Z. A., Sasongko D., Susilowati N. D. 2015. Screening of Rhizosphere Bacteria from Rice Fields in Coastal Area as ACCDeaminase and Auxin Producer. Journal. Ijaseit. Vol.5 (2015) No. 1 ISSN: 2088-5334

[11] Rahmah A., Sipayung R., and Simanungkalit T. 2013. Growth And Production of Shallot (Allium ascalonicum L.) By Addition of Chicken Manure and EM4 (Effective Microorganisms 4). The University of North Sumatra. Medan. 
[12] Rahni, 2012. Effects on Growth Phytohormone of maize (Zea mays). Articles. Lecturer of Agrotechnology in Haluoleo University. Southeast Sulawesi.

[13] Rajiman, Yudono P., Sulistyaningsih E., and Hanudim E. 2008 Influence Settling Soil Properties Against Soil Physics and Yield of Shallots On Sandy Coastal Land in Bugel Kulon Progo. Agrin Journal Vol. 12, No. 1

[14] Setiawan, Tohari and Shidieq D. 2012. Effect of Drought Stress Against Plant Proline Accumulation Patchouli (Pogostemon cablin Benth.) Journal. Agricultural Science Vol. 15. No.2. 2012: 85 - 99. Faculty of Agriculture. Gadjah Mada University. Yogyakarta.
[15] Sutariati GAK, Safuan LO. 2012. Seed Treatment with Rhizobacteria Improve Seed Quality and Yield of Chili (Capsicum annum L). Agron J Indonesia. 40 (2): 125- 131.

[16] Watanabe. I. R. So. J. K. Ladha. Y. Katayama-Fujimura and H. Kuraishi. Nitrogen fixing 1987. A New Species of pseudomonads: Pseudomonas diazotrophichus. Isolated from Rice. Can J Microbiol 33: 670-678.

[17] Yetti, H, and Elita, E., 2008. The Use of Organic Fertilizer and $\mathrm{KCl}$ on Shallots. Vol. 7 No. 1: 13-18. Faculty of Agriculture. The University of Riau. Riau. 